\title{
RIGHT TO COUNSEL AT THE PRETRIAL MENTAL EXAMINATION OF AN ACCUSED
}

In United States v. Wade, ${ }^{1}$ the Supreme Court held that a defendant in a criminal case enjoys the right to counsel at a postindictment lineup. The Court found that certain police practices were sufficiently suggestive to taint the credibility of an identifying witness and that counsel's ability to discredit a mistaken identification effectively hinged on his knowledge of the methods employed by the police. Consequently, a post-indictment lineup was a "critical stage of the prosecution," 2 at which the sixth amendment mandates the presence of counsel to preserve the accused's right to a fair trial. ${ }^{3}$

The Wade holding provided the basis for the petitioner's argument in Thornton $v$. Corcoran, ${ }^{4}$ that counsel is similarly required at pretrial mental examinations. Charged with the rape of an eleven year old girl, Thornton requested a mental examination. ${ }^{5}$ When District Court Judge Corcoran refused to order Saint Elizabeths Hospital (a federal institution) to permit attendance of Thornton's counsel and privately retained psychiatrist at the hospital staff conference, ${ }^{8}$ Thornton petitioned the Court of Appeals for the District of Columbia for a writ of mandamus to compel Judge Corcoran to fulfill his "duty." ? Chief Judge Bazelon, writing for the majority, denied mandamus because the "extraordinary writ" 8 could only be issued in exceptional circumstances not present in this case ${ }^{9}$ but he discussed the merits of

1388 U.S. 218 (1967).

2 Id. at 237 .

3 See 388 U.S. at 226-27 (1967). For a more complete discussion of the Wade rule, see Comment, Right to Counsel at Scene-of-the-Crime Identifications, 117 U. PA. L. REv. 916, 916-19 (1969).

4407 F.2d 695 (D.C. Cir. 1969).

5 The examination was requested under D.C. CODE ANs. $\$ 24-301$ (a) (1967). 407 F.2d at 696 .

6 Both petitioner's competency to stand trial and his mental status at the time of the crime were to be determined at the staff conference. 407 F.2d at 696 .

7 Id. at 698 .

8 Id. at 697 .

9 The court relied heavily on Will v. United States, 389 U.S. 90 (1967), in which the Supreme Court reversed a decision by the Court of Appeals for the Seventh Circuit which granted mandamus. After discussing the extraordinary nature of mandamus when directed against judges and the exceptional circumstances required to justify the writ, the Court reversed because no evidence of such circumstances appeared in either the trial record or the circuit court's opinion.

Will is distinguishable from Thornton since it was the government which petitioned for mandamus in the former, thereby injecting the additional issues regarding double jeopardy and the defendant's right to a speedy trial. Judge Bazelon recognized but discounted the distinction, stating that the Will opinion "must chill the enthusiasm of any intermediate court to issue such an extraordinary writ in any criminal case." 407 F.2d at 697 . Instead, he proceeded to examine at length the merits of petitioner's constitutional claim, ostensibly to meet the Will requirement for "findings of fact by the 


\section{the constitutional claim nonetheless. ${ }^{10}$}

Judge Bazelon began with a comparison of the psychiatric examination to simpler scientific, evidentiary tests-such as fingerprinting or blood sampling-to which the Wade mandate does not apply, because counsel's presence during administration of the test is unnecessary to assure meaningful cross-examination at trial. He found that, unlike these simpler tests, "there is at best small agreement among experts concerning either the theory or technique appropriate to the diagnosis of mental illness." $11 \mathrm{He}$ went on to discuss the danger that an accused will incriminate himself during a psychiatric examination; ${ }^{12}$ the argument that the intimacy necessary to a psychiatric examination would be disrupted by the presence of a third party; ${ }^{13}$ the insubstantiality of this argument as applied to staff conferences; ${ }^{14}$ and the problems faced by attorneys unfamiliar with the nuances of psychiatry and confronted with hospitals not eager to provide reports and files relevant to the examination. ${ }^{15}$ Although not detailed, Judge Bazelon's discussion touched on nearly all of the issues pertinent to counsel's presence at the examination; much of what follows in this Comment is a closer look at several of these issues.

The Supreme Court in Wade described a critical stage as "any stage of the prosecution, formal or informal, in court or out," 16 where

issuing court and some statement of the court's legal reasoning." $I d$, at 698, citing 389 U.S. at 107.

Yet, even under Will, the court was not obliged to discuss the merits of the petitioner's constitutional claim. Will dealt specifically with a court which had issued the extraordinary writ; in Thornton the writ was denied. Regardless of the patent desirability of explicitly reasoned opinions, a refusing court is not under the same obligation to explain itself as an issuing court.

10 Judge Burger (now Chief Justice of the Supreme Court of the United States) strongly dissented from this approach, finding Judge Bazelon's discussion of the merits of the constitutional claim "totally dicta." 407 F.2d at 704. Judge Burger raised the most frequently advanced arguments against permitting counsel to attend the psychiatric examination: that the examination is not a confrontation of the accused at a critical stage of the prosecution but is rather a fact-finding process, $i d$. at 711 , and that the intimacy necessary for a successful examination would be disturbed by the intrusion of a third party, whose very presence in the person of counsel would transform the examination into an adversary proceeding. Id. His arguments are buttressed by the weight of authority. See, e.g., United States v. Albright, 388 F.2d 719, 726 (4th Cir. 1968) (presence of third party in legal and non-medical capacity would severely limit the efficacy of the examination); Timmons v. Peyton, 240 F. Supp. 749, 753 (E.D. Va. 1965), rev'd on other grounds, 360 F.2d 327 (4th Cir. 1966) (state mental institutions cannot by the presence of attorneys be thwarted in their efforts to accomplish the purpose of intelligent examinations); In re Spencer, 63 Cal. $2 \mathrm{~d} 400,406$ P.2d 33, 46 Cal. Rptr. 753 (1965) (presence of counsel not constitutionally required so long as defendant is represented by counsel, and testimony of examining psychiatrist at trial is not considered as evidence of guilt); State v. Snyder, 180 Neb. 787, 146 N.W.2d 67 (1966) (defendant who submits to or requests examination by court-appointed psychiatrist is not constitutionally entitled to presence of counsel at examination); State v. Whitlow, 45 N.J. 3, 210 A.2d 763 (1965) (trial court did not abuse its discretion in declining to permit counsel to witness the state's examination).

11407 F.2d at 699 .

12 Id. at $699-700$.

13 Id. at 701.

14 Id.

$15 \mathrm{Id}$. at 701-02.

16388 U.S. at 226. 
"the presence of . . . counsel is necessary to preserve the defendant's basic right to a fair trial as affected by his right meaningfully to crossexamine the witnesses against him and to have effective assistance of counsel at the trial itself." 17 Thus the question arises whether the purposes and procedures of the pretrial mental examination are such that it should be characterized as a critical stage requiring counsel's presence to protect the accused's sixth amendment rights. ${ }^{18}$

The defense, the prosecution, or the court may raise the issue of the accused's sanity ${ }^{10}$ to determine his present competency to stand trial, ${ }^{20}$ his sanity at the time of the alleged crime, or both. Regardless of whether the defendant seeks to establish sanity or insanity, he should be informed of the methodology employed by the opposing psychiatrists so that he is able to challenge effectively their conclusions.

The amount of time spent in active examination of the defendant by the court-appointed psychiatrist varies greatly among jurisdictions. ${ }^{21}$ In the District of Columbia, defendants of questionable sanity who are accused of felonies are sent to Saint Elizabeths Hospital, usually for sixty days, for a determination of both competency and responsibility for the alleged crime.22 A psychiatric resident in training and a social worker take independent case histories of the defendant, the former immediately after admission and the latter within the first thirty days. A psychiatric resident in training also conducts two or three thirty

17 Id. at 227.

18 Although apparently not raised by petitioner, Mempa v. Rhay, 389 U.S. 128 (1967), provides further support for his position. In $M e m p a$, the Supreme Court held that a criminal defendant is entitled to presence of counsel at a combined revocation of probation and deferred sentencing hearing. The Court stated: "[T] he necessity for the aid of counsel in marshaling the facts, introducing evidence of mitigating circumstances and in general aiding and assisting the defendant to present his case as to sentence is apparent." Id. at 135. Since counsel's aid and assistance are also necessary in pretrial mental examinations, $M$ empa becomes relevant because both parole revocation-sentencing hearings and pretrial mental examinations may be conventionally viewed as outside the scope of the prosecutorial process, yet both may entail opportunity for denial of sixth amendment rights of the defendant.

19 See Judicial Conference of the District of Columbia Circuit, Report of the Commtrtee on Problems Connected with Mental Examination of the ACCUSEd IN CRIMINAL CASES, Before TRIAL 19-20 (1966) [hereinafter cited as Judicial REPORT]; Comment, Commitment to Farview: Incompetency to Stand Trial in Penusylvania, I17 U. PA. L. REv. 1164, 1174-81 (1969) [hereinafter cited as Commitment to Farviezo]. Several states provide for automatic pretrial mental examinations under specific circumstances. See, e.g., Colo. Rev. Stat. AnN. \& 39-8-2 (1963); Mass. ANN. LAwS ch. 123, §100A (1965).

20 When the defendant's competency is questioned, there is a danger that the ensuing mental examination may actually be a search for incriminating evidence. See Krash, The Durham Rule and Judicial Administration of the Insanity Defense in the District of Columbia, 70 YALE L.J. 905, 911 (1961) [hereinafter cited as Krash]. The danger raises fifth amendment problems which are beyond the scope of this Comment. For an informative discussion of the question of self-incrimination and the admissibility of psychiatric testimony, see Note, Pre-trial Mental Examination and Commitment: Some Procedural Problems in the District of Colunbia, 51 GEo. L.J. 143 (1962).

21 A. Goldstein, The Insanity Defense 132 (1967) [hereinafter cited as GoLDSTEIN]. $27-34$.

22 The ensuing discussion of the examination process is based on JUDICIAL REPORT 
minute interviews with the defendant and then submits summaries of the interviews to the staff psychiatrists for evaluation at the staff conference. Nurses and ward attendants send observations of unusual behavior to the staff conference. ${ }^{23}$ The defendant takes approximately five psychological tests during his stay. ${ }^{24}$

A final decision on the defendant's mental condition is reached at the staff conference. ${ }^{25}$ In many cases a defendant speaks with a senior staff psychiatrist for the first and only time at this conference, which may also be attended by staff physicians, a psychologist, a social worker, and residents in training. ${ }^{26}$ The staff members interview the defendant for twenty to thirty minutes, and then privately discuss his condition among themselves. From this conference emerges the hospital's official diagnosis of the accused.

Diagnostic theories leading to official conclusions are, to use Judge Bazelon's word, "legion." 27 In Martin v. United States, ${ }^{28}$ the defense called four psychiatrists and the Government two. On the question of the causal connection between mental illness and the alleged criminal acts of possession and sale of narcotics, the defense experts responded that the connection was: (1) possible, (2) probable, (3) a strong probability, and (4) of necessity. Of the Government's experts, one could form no opinion, and the other found "probably no connection." It is unnecessary to question the impartiality of psychiatrists ${ }^{29}$ to reach the conclusion that an individual doctor's diagnostic techniques and psychiatric school of thought undoubtedly influence his final opinion. Thus, counsel's absence and inability to note the procedure followed by the examining psychiatrist certainly "might derogate from the accused's right to a fair trial" ${ }^{30}$ by increasing the difficulty counsel faces in attempting to refute the prosecution's expert witnesses. ${ }^{31}$

23 Such observations are usually insignificant factors in assisting psychiatric determinations. JUDYCIAL REPORT 102.

${ }^{24}$ These tests include the Wechsler Bellevue Intelligence Scale, Wechsler Memory Scale, Bender-Gestalt, Rorschach and Projective Drawings, and others. Judicial REPORT 32.

25 A staff conference "is a quasi-formal review of a patient's status by the . . . treatment staff of the institution." Commitment to Farvieze 1188 n.144.

26 The hospital tries to limit the number of attending psychiatrists who might be subpoenaed to testify at trial. JUDICLAL REPORT 33 .

27407 F.2d at 699; see GordSTEIN 133:

An impartial expert, and the added credibility he brings with him, could be justified only if there was a high degree of consensus among psychiatrists on the answers to questions likely to arise in the courtroom, on the qualifications of persons competent to present such answers and on the techniques to be used at the various stages of the examination. No such consensus can be said to exist.

28284 F.2d 217 (D.C. Cir. 1960).

20 See genterally GoLDSTEIN 133.

30 United States v. Wade, 388 U.S. 218, 226 (1967).

31 Cf. Henderson v. United States, 360 F.2d 514, 520-21 (D.C. Cir. 1966). 
The usual response to this argument is that the accused is adequately protected by his counsel's ability to obtain reports from the examining psychiatrists. But as Judge Bazelon pointed out:

[T] he hospital [Saint Elizabeths] has not displayed an enthusiasm to make such reports available to the defense. As recently as last year it refused to allow a defense psychiatrist access to the reports of its staff psychologist. $^{32}$

Furthermore, when reports are made available, they are often so conclusory as to be uninformative. ${ }^{33}$ For example, in Calloway v. United States, ${ }^{34}$ the report read:

Psychiatric examination reveals this patient to be sane, competent and capable of participating in his own defense. He may be returned to the Court at any time. ${ }^{35}$

Such reports obviously provide "no basis for knowing the standard applied by the psychiatrist or the factors taken into account by him in reaching his conclusion that the defendant is or is not fit to stand trial." 36

Many reports are incomplete as well as uninformative since some hospitals do not record dissenting views to the final submitted report. Further, some psychiatrists, wishing to avoid court appearances, have been unwilling to submit detailed reports which might become provender for subsequent legal attack. ${ }^{37}$ Thus, in many cases, the hospital's report is of little value to defense counsel.

The need for defense scrutiny of the diagnostic process is increased by another practice of some examining psychiatrists:

It has been suggested that with a broadening in the standard of criminal responsibility [in the District of Columbia due to the decision in Durham v. United States ${ }^{38}$ ] there is less incentive for a psychiatrist to submit an evaluation that suggests (or concludes) that the accused is incompetent to stand trial. The reason is that the psychiatrist can be reasonably certain that the accused ultimately will be returned to the hospital following an acquittal by reason of insanity. If one assumes an accused who medically suffers from a mental

32407 F.2d at 702.

33 See Judictal RePort 36 \& n.1, 118. This situation may have changed in the District of Columbia. Judge Bazelon has on more than one occasion requested that Saint Elizabeths Hospital return more detailed reports. Id. $v$.

34270 F.2d 334 (D.C. Cir. 1959).

35 Id. at 335 .

36 Krash 914.

37 JUdiciat REPORT 36.

38214 F.2d 862 (D.C. Cir. 1954). 
disorder that makes it likely that he is both incompetent to stand trial and not responsible, then the psychiatrist may in some cases be inclined to report that the accused is fit to stand trial and rely on the high probability that he will be acquitted by reason of insanity. ${ }^{39}$

Admittedly this psychiatrist's gambit is undertaken out of professional concern for the accused, because treatment pointing toward freedom is more effective than treatment leading to a pronouncement of competency to stand trial. ${ }^{40}$ Nevertheless, the risk exists that an incompetent, innocent defendant will go to trial unable to present adequately a defense perhaps entitling him to acquittal. ${ }^{41}$ Because he is unable to participate effectively in his own defense, returning an incompetent to trial denies him his right to a fair trial. ${ }^{42}$ Consequently, counsel should be aware of the reasons supporting a finding of competency in order to protect the accused's sixth amendment rights.

Valid reasons in support of a finding of incompetency may also impinge on the accused's rights to a speedy trial. Some psychiatrists, again acting out of professional concern, will occasionally refuse to declare a defendant competent regardless of legal criteria if in their opinion he is too dangerous to be allowed on the streets, or may be unable to stand the stress of trial. ${ }^{43}$ The resultant period of confinement frequently exceeds the maximum allowable term of imprisonment for the alleged crime. ${ }^{44}$ If the accused was in fact legally competent to stand trial, this extended confinement obviously denies him a speedy trial.

Thus, inconsistent or contradictory diagnoses varying with the psychiatric methodology employed, disregard for relevant legal criteria in determinations of competency, and incomplete or conclusory staff reports, indicate that counsel's presence may be necessary to enable him adequately to conduct subsequent cross-examination. But however critical to the defendant's case the examination may be, the question remains whether it is a stage of the prosecution.

The Wade Court was concerned with situations in which "law enforcement machinery involves critical confrontations of the accused by the prosecution at pretrial proceedings . . . ." 45 Insofar as the prosecution confronts the accused during a pretrial mental examination,

39 Judictal. Report 45.

40 See Commitment to Farview 1170-72 \& nn.37-39.

41 See Judictar Report 45-46. Psychiatrists at the Psychiatric Division of the Department of Probation of the Courts of Common Pleas of Philadelphia reportedly resolve doubts about competency in favor of competency in order to dispose of the criminal charges pending against the patient. Commitment to Farview 1181.

42 See Pate v. Robinson, 383 U.S. 375, 378 (1966).

43 See Commitment to Farview 1191. See generally GoLDSTEIN 125.

44 See Commitment to Farview 1165-67, 1194.

45388 U.S. at 224. 
the examination to that extent becomes a stage of the prosecution. In theory the examination is a discrete process, separate from the prosecutorial apparatus. But in practice, most criminal defendants in the District of Columbia are indigent and thus must rely on examiners appointed by the court and provided by the state. ${ }^{46}$ As Judge Bazelon remarked, many of the examining doctors testify for the government at trial. ${ }^{47}$ Ideally the examining psychiatrists seek only an impartial determination of the defendant's mental condition; but Saint Elizabeths Hospital, "within the executive branch of the Government and manned by persons on the executive branch payroll," has more than once been accused of being "government-oriented in its general attitude." 48 Additionally,

[t]he prosecution itself has increasingly taken the initiative in requesting the court to order pretrial mental examinations, particularly in capital cases. The government's primary objective, however, is not to establish the accused's fitness to stand trial, but rather to gather evidence respecting the defendant's mental condition as of the date of the crime in order to rebut any claim of insanity at the time of the offense should such a defense be subsequently raised. ${ }^{49}$

Thus, the pretrial mental examination can become a discovery tool for the prosecution, jeopardizing the accused's privilege against selfincrimination if adequate safeguards are not established. ${ }^{\mathbf{5 0}}$

Of course, not every mental examination jeopardizes the defendant's rights. Perhaps the most serious threat arises when government supported institutions examine the accused, find him sane, and thereby either remove the last impediment to conviction or even provide the prosecution with evidence necessary for a conviction. ${ }^{51}$ But even examination by private practitioners affords opportunity for abuses of the accused's rights such as have been discussed above: and although only upon actual testimony at trial by the psychiatrist does the examination become an ex post facto interrogation, ${ }^{52}$ the examina-

46 See Judictal Report 17.

47407 F.2d at 699.

48 E.g., Judictal Report 97.

49 Krash 911 (footnotes omitted).

50 In Johnson v. United States, 344 F.2d 401 (5th Cir. 1965), the accused had undergone a competency examination. At trial, the doctors testified on the accused's sanity at the time of his alleged crime. The accused was convicted. Although the Fifth Circuit reversed the conviction, the court indicated that the doctors' testimony would have been admissible had they in fact investigated the accused's criminal responsibility even though the examination was ostensibly to ascertain present competency. Id. at 407.

51 See Thornton v. Corcoran, 407 F.2d 695, 699 (1969).

52 In Escobedo v. Illinois, 378 U.S. 478 (1964), the Supreme Court defined interrogation as a critical stage of the prosecution. Id. at 488 . 
tion may nevertheless qualify (as when legal criteria of competency are disregarded to the detriment of the accused's rights) as a "critical stage of the proceedings." 53

The most important traditional policy argument for excluding counsel has yet to be discussed: that the intimate nature of psychiatric examinations would suffer if third parties were introduced. ${ }^{54}$ State $v$. Whitlow ${ }^{55}$ is often cited in support of exclusion of counsel. ${ }^{56}$ The defendant there requested the presence of his counsel at his competency examination to protect his privilege against self-incrimination. In refusing the request, the New Jersey Supreme Court did establish extensive safeguards against self-incrimination during the examination. Then, turning directly to the issue of counsel's presence, the court stated:

Having in mind the nature of psychiatric examinations, the usual necessity for an extensive interview between the doctors and the defendant, and the safeguards now established against use of possible inculpatory statements of the accused as substantive evidence of guilt, we see no absolute duty on [sic] the trial court to permit the defense attorney to be present with his client; the matter rests in the court's discretion. If upon application by the State for leave to examine, defense counsel requests permission to be present at the examination, the court should require some showing by the prosecutor as to the attitude of the psychiatrists about the presence of counsel. Of course, if there is no objection, permission should be granted. (In such case, counsel should realize his attendance is in the capacity of an observer, not an active participant.) If, in their view, the presence of such a nonprofessional would hinder or operate to reduce the effectiveness of their examination, or if they assert they cannot examine in his presence, the court may in the exercise of its discretion exclude counsel from the examination. In this event, if defendant requests, consideration may be given to the feasibility of

53 United States v. Wade, 388 U.S. 218, 224 (1967). The Supreme Court in Wade used the term "critical stage of the prosecution" interchangeably with "critical stages of the proceedings." Compare id. at 226, 237 with id. at 224, 225. The problem with the former is the difficuity of determining before trial what actually is a stage of the prosecution. For example: John Smith, arrested for drunken driving in a jurisdiction providing for optional breathalyzer tests, insists on taking such a test. Negative results will probably not be used by the prosecution at trial, and the test would probably not be called a stage of the prosecution. Positive results will be used by the prosecution, thus qualifying the test, although voluntarily taken, as a stage of the prosecution. The "critical stage of the proceedings" formula avoids this problem.

54 This argument was made by Judge Burger in his dissent. 407 F.2d at 711. For cases supporting this position, see note 10 supra.

5545 N.J. 3, 210 A.2d 763 (1965).

56 See, e.g., United States v. Albright, 388 F.2d 719, 726 (4th Cir. 1968); In re Spencer, 63 Cal. 2d 400, 413, 406 P.2d 33, 42, 46 Cal. Rptr. 753, 762 (1965). 
permitting such devices as recording instruments or the like to be utilized at the psychiatric interview. In any case the court should allow a defense psychiatrist to attend the examination, if such a demand is made. ${ }^{57}$

It is significant that the court referred repeatedly to the right of the defense psychiatrist to attend the examination conducted by state psychiatrists. If the presence of a professional psychiatrist is not seen as a hindrance to the examination, then neither should the presence of an attorney. The court cautioned counsel that observation alone was appropriate. But an attending defense psychiatrist would not participate in the examination. It would appear that either the psychiatrist or attorney present at the examination would observe only, ${ }^{58}$ and it is unlikely that the examination would be any more disrupted by the silent presence of one professional rather than another.

One further consideration favoring counsel's presence is the possible beneficial effect attending counsel might have on the productivity of the examination. An emotionally overwrought defendant (whether or not incompetent or irresponsible), committed to a large, impersonal hospital for sixty days, may view his examining doctors with apprehension. The reassuring presence of counsel could do much to alleviate the accused's feelings of isolation and distrust, and in fact contribute to the effectiveness of an examination otherwise hindered by the accused's reluctance to respond freely to the psychiatrist.

Defense counsel should also be permitted to attend the staff conference. The contention that the presence of counsel would disrupt the intimate doctor-patient relationship is inapplicable to staff conferences, where, as Judge Bazelon pointed out, the defendant "faces a number of staff members, most of whom he has never seen before." 59 On the other hand, the problem of self-incrimination persists as long as the defendant is being interviewed during the conference. After the interview, when the staff discusses and evaluates the defendant, counsel's presence as an observer should in no way interfere. The conference is the most important stage of a mental examination, because it is here that the impressions of the examiners and the results of the psychiatric tests are evaluated. Here, the dissenting doctors express their conclusions. Here, the defense counsel can obtain vital information without disrupting the doctor-patient relationship. ${ }^{60}$ Here also, the accused's immediate fate may well be decided. ${ }^{\circ 1}$

5745 N.J. at 27-28, 210 A.2d at 776 (emphasis added).

58 However, counsel might interfere in some circumstances: for example, where the examining psychiatrist was pressuring the accused for details of the alleged crime, and counsel feared that any resultant admissions might be used at trial in support of the psychiatrist's determination of sanity. In any event, such interference would have to be minimal.

59407 F.2d at 701.

$60 \mathrm{See}$ id.

61 Text accompanying notes $38-44$ supra. 
Judge Bazelon never explicitly recognized this right to counsel, but he did state that

[t]he petitioner's claim that the logic of United States v. Wade should apply to his staff conference at Saint Elizabeths Hospital is therefore anything but frivolous. If his right to cross-examine the witnesses against him can be protected in no other way, his argument is of constitutional dimensions. ${ }^{62}$

With the effectiveness of the accused's right to cross-examine and his right to a fair and speedy trial hanging in the balance, the court should either permit counsel to attend the staff conference, or devise equally effective alternatives to protect these rights. ${ }^{63}$

62407 F.2d at 702.

63 The Supreme Court in United States $v$. Wade recognized that legislation could eliminate the dangers inherent in a lineup and thus remove it from the "critical stage" category. 388 U.S. at 239 . If effective alternatives were constructed for mental examinations, counsel's presence would be unnecessary. See Thornton v. Corcoran, 407 F.2d 695, 702 (D.C. Cir. 1969). 